\title{
PEMBUATAN PAPAN NAMA KEPALA LINGKUNGAN DAN IMAM LINGKUNGAN
}

(KELURAHAN BONTOTANGNGA KEC.TAMALATEA)

NAMA : TITIK KAMAL

NIM : 9173770410181

EMAIL : ktiti0573@gmail.com

1. Bentuk Kegiatan

- Pembuatan papan nama Kepala Lingkungan dan Imam Lingkungan

2. Lokasi

- Posko KKLP di Kelurahan Bontotangnga Kec. Tamalatea

3. Hari Tanggal Dan Waktu

- Hari Kamis, Tanggal 15 Oktober 2020 Pukul 11.00 Wita

4. Peserta Yang Dilibatkan

- Mahasiswa KKLP YAPTI JENEPONTO

5. Alasan Yang Diadakannya

- Setelah Observasi Lapangan, kami melihat beberapa papan nama lingkungan perlu di perbaharui.

6. Tujuan Dan Manfaat

- Kami mengadakan program kerja ini, agar masyarakat lebih mudah mengetahui rumah aparat di suatu lingkungan tersebut.

7. Deskripsi Kegiatan

- Proses pembuatan papan nama Lingkungan dan imam lingkungan kami lakukan selama beberapa hari. Proker ini dilakukan sebagai upaya memberikan kemudahan terhadap Masyarakat setempat mengenali rumah aparat lingkungan tersebut. 